\title{
Esophagus and Esophagogastric Junction Cancer pT4b TNM Finding v8
}

National Cancer Institute

\section{Source}

National Cancer Institute. Esophagus and Esophagogastric Junction Cancer pT 4b TNM

Finding v8. NCI Thesaurus. Code C133384.

Esophagus and esophagogastric junction cancer with tumor invading other adjacent

structures, such as the aorta, vertebral body, or airway. (from AJCC 8th Ed.) 